\title{
AMBULATORINIŲ ASMENS SVEIKATOS PRIEŽIŪROS PASLAUGŲ PRIEINAMUMAS IR SAUGA EKSTREMALIOS SITUACIJOS METU DÉL COVID-19
}

\author{
Jelena Kutkauskienė \\ Mykolo Romerio universiteto Teisès mokyklos Viešosios teisès institutas
}

\begin{abstract}
Raktažodžiai: COVID-19 pandemija, sveikatos priežiūros įstaigos, paslaugos COVID-19 sergantiesiems.

Santrauka

Ekstremalios situacijos metu poreikis efektyviai valdyti situaciją nulėmé poreikị keisti ir iš esmès vykdyti teisinị reguliavimą. Šiame straipsnyje aptariami svarbiausi sprendimai, kuriais buvo siekiama perorganizuoti ir plètoti ambulatorinių asmens sveikatos priežiūros paslaugų teikimą ekstremalios situacijos metu, ivvertintos teisinès priemonès, užtikrinusios šių paslaugų prieinamumą ir saugą.
\end{abstract}

\section{Ivadas}

LR Konstitucinis Teismas 2013 m. gegužès 16 d. nutarime pažymėjo, kad vykdydama konstitucinę funkciją rūpintis žmonių sveikata valstybė „turi: < ..> sudaryti sąlygas, kad sveikatos priežiūros paslaugos būtų visiems realiai prieinamos, taigi kad būtų sukurta reikiama infrastruktūra ir veiktų tiek ir taip paskirstytų ịvairias sveikatos priežiūros paslaugas teikiančių i̦staigų (tarp jų valstybinių) ir vaistinių, kad veiksmingą medicinos pagalbą bei kitas sveikatos priežiūros paslaugas būtų galima gauti laiku; <...> sukurti tokią sveikatos priežiūros finansavimo sistemą, kuri užtikrintų reikiamų sveikatos priežiūros paslaugų ir būtinų vaistų finansinį prieinamumą (ịperkamumą)" [1].

2020 m. sausio 30 d. Pasaulio sveikatos organizacija (toliau - PSO) paskelbè visuomenès sveikatos grèsmès situaciją dèl sparčiai plintančio naujojo koronoviruso - šeimos COVID-19 viruso (toliau - COVID-19). Šios grèsmès akivaizdoje ypatingą aktualumą igijo $2005 \mathrm{~m}$. PSO pateiktos tarptautinès rekomendacijos [2] visuomenès sveikatos saugos srityje, kurios numate šias penkias pagrindines kryptis: prevenciją, nustatymą, atsaką, igalinimą ir funkcinị pasirengimą. 182 šalių ataskaitų per 2018 metus studija atskleidè skirtingą šalių pasirengimo visuomenès sveikatos grèsmei atremti lygị ir, nors Europos regiono šalių funkcinis pasirengimas yra aukšto lygio ( 4 ar 5 balai iš galimų 5 balų) [3], retrospektyviai tikslinga ịvertinti, ar Lietuvoje priimti specialieji teisiniai sprendimai po valstybès lygio ekstremaliosios situacijos paskelbimo visoje šalyje dèl COVID-19 plitimo grèsmès [4] užtikrino paslaugų organizacinị ir finansini prieinamumą. Šios temos aktualumą suponuoja ir mokslininkų ižzalga: jei ịprastai sveikatos priežiūros sprendimai priimami remiantis medicinos mokslo įrodymais, COVID-19 pandemijos metu vykdomajai valdžiai teko atsakomybė priimti skubius sprendimus, dar nesant mokslinių įrodymų bei ịgyvendinti tarptautines rekomendacijas, pritaikant jas specifinèms lokalioms sąlygoms [5].

$2020 \mathrm{~m}$. laikotarpis po valstybès lygio ekstremaliosios situacijos paskelbimo visoje šalyje dèl COVID-19 plitimo grèsmès pasižymėjo ypač gausiomis teisèkūros naujienomis sveikatos teisès srityje. Lietuvos Respublikos Vyriausybès 2020 m. kovo 14 d. nutarimu Nr. 207 [6] reikšmingai apribotas planinių asmens sveikatos priežiūros paslaugų (toliau - ASPP) teikimas. O operacijų vadovo - sveikatos apsaugos ministro - įsakymais iš esmès buvo keičiamas ambulatorinių ASPP (toliau - AASPP) teikimo organizavimas, diegiant naujas jų teikimo pacientams organizacines struktūras - karščiavimo klinikas, mobiliuosius punktus, karštają liniją 1808 bei teisinemis priemonèmis įtvirtintas epidemiologiškai saugių ASPP teikimo reikalavimas. Teisès aktai $[7,8]$, ipareigojantys savivaldybes steigti šiuos padalinius, atsirado praëjus vos dešimčiai dienų po karantino paskelbimo ir neabejotinai prisidejjo prie sėkmingo pirmosios COVID-19 bangos suvaldymo Lietuvoje.

Epidemiologinès situacijos valdymas susijęs su konkrečiais grèsmę keliančiais virusais - COVID-19. Siekimas užtikrinti ambulatorinių asmens sveikatos priežiūros paslaugu prieinamumą ir saugą reikalavo operatyvaus teisinio reguliavimo, kurị santykinai galima suskirstyti į šias pagrindines kryptis: reguliavimas, nustatantis ypatingą epidemiologini režimą asmens sveikatos priežiūros ịstaigose (toliau - ASPİ), asmens sveikatos priežiūros paslaugų teikimo reguliavimo 
pokyčiai ekstremalios situacijos metu.

Šiuo metu nẻra daug socialinių mokslų krypties straipsnių, nagrinèjančiu įvairių šalių patirtí, suvaldant pandemiją. Daugelis jų skirti suvaldymo priemonių, e.sveikatos paslaugų diegimo galimam poveikiui [9-11] ar asmens apsaugos priemoniu (toliau - AAP) [12] reglamentavimo problemoms nagrinèti, keliamas klausimas dèl pandemijos metu priimtų sprendimų legitimumo ir skaidrumo [13].

Tyrimo tikslas - atlikti svarbiausių teisès aktų pakeitimų, kuriais buvo siekiama užtikrinti ambulatorinių asmens sveikatos priežiūros paslaugų prieinamumą ir saugą ekstremaliosios situacijos metu, analizę bei ịvertinti jų teisinį pagrịstumą.

Tyrimo metodai - sisteminès analizès, loginis, dokumentų analizès metodai.

\section{Tyrimo rezultatai}

Reguliavimai, nustatantys ypatingą epidemiologinị režimą asmens sveikatos priežiūros įstaigose. Lietuvos Respublikos žmonių užkrečiamųjų ligų profilaktikos ir kontrolès ịstatymo [14] (toliau - LR ŽULPKİ) 8 str. 2 d. nustato, kad sveikatos apsaugos ministras (toliau - SAM) tvirtina pavojingų ir ypač pavojingų užkrečiamujų ligų, dẻl kurių asmenys, užsikrètę šia liga, turi būti hospitalizuojami, izoliuojami, tiriami ir (ar) gydomi privalomai, sąrašą. $2020 \mathrm{~m}$. kovo $17 \mathrm{~d}$. COVID-19 buvo priskirta prie ypač pavojingų užkrečiamuju ligų [15]. COVID-19 įtraukimas ị ypač pavojingų užkrečiamujjų ligų sąrašą sukelia daugelị teisinių pasekmių.

Pirma, ligoniams, asmenims, ittariamiems, kad serga ar turèję sąlytị, taikomi visuomenès sveikatos imperatyvų pateisinami jų laisvių suvaržymai - jie turi būti atitinkamai hospitalizuojami ir (ar) izoliuojami, o nesutinkantiems asmenims taikomi būtinojo hospitalizavimo ir (ar) izoliavimo reikalavimai [14, 8 ir 9 str.].

Antra, ligoniams, asmenims, itariamiems, kad serga ar turèjo sąlytị su COVID-19 sergančiaisiais, dèl ypatingo epidemiologinio režimo taikomos papildomos socialinès garantijos [16].

Trečia, draudžiamieji asmenys, susirgę COVID-19, igyja apdraustụjų valstybės lěšomis statusą [17], t.y. jiems teikiamos ASPP apmokamos iš Privalomojo sveikatos draudimo fondo biudžeto (toliau - PSDF) lěšų. O tai reiškia, kad valstybė pagal LR Konstitucijos 53 str. [18] ịtvirtintą pareigą rūpinasi žmonių sveikata ir laiduoja medicinos pagalbą susirgus. Visiems Lietuvos Respublikos teritorijoje teisètai esantiems asmenims buvo suteikta finansinio prieinamumo garantija. Toks draudžiamujų asmenų kategorijos išplėtimas leido išvengti situacijos, susiklosčiusios Jungtinèse Amerikos Valstijose (toliau - JAV), kur dažnas COVID-19 pacientas neturejjo sveikatos draudimo [5].

2020 m. kovo 14 d. Lietuvos Respublikos Vyriausybès nutarimu Nr. 207 [6] paskelbus visoje Lietuvos Respublikos teritorijoje karantiną, nustatytas ASPI darbo organizavimo režimas paliete visų rūšių asmens sveikatos paslaugų teikimą. Teikiant ambulatorines ASPP (toliau - AASPP) buvo pereita prie nuotolinių paslaugų teikimo; atidètos planinès operacijos ir hospitalizacijos dèl diagnostinių ir gydomujų paslaugų, išskyrus pagalbą ir ASPP, kurių nesuteikus pacientui atsirastų būtinosios medicinos pagalbos poreikis arba labai pablogètų jo būklè; uždraustas pacientų lankymas, išskyrus terminalinès būklès pacientų ir vaikų iki 14 metų lankymą gydančio gydytojo leidimu; apribotas medicininès reabilitacijos paslaugų teikimas, išskyrus tuos atvejus, kurių nesuteikimas lemtų paciento neiggalumą; pacientų namuose teikiamos tik ambulatorinès slaugos ir paliatyvios pagalbos paslaugos; atidètos ambulatorinès medicininès reabilitacijos, odontologijos, išskyrus būtinosios medicinos pagalbos, profilaktinių patikrinimų ir prevencinių programų paslaugų teikimas; planiniai skiepijimai vykdomi igyvendinus pacientų srautų valdymo reikalavimus [6]. Minètas nutarimas ịpareigojo ASPI perorganizuoti veiklą, siekiant užtikrinti pacientų srautų, infrastruktūros ir materialiųų bei žmogiškųjų išteklių valdymą, atitinkantị pandemijos valdymo priemones. Kontaktinių ASPP teikimo epidemiologinį režimą (infekcijos kontrolès reikalavimus) nustate SAM 2012 m. spalio 19 d. îsakymu Nr. V-946 patvirtinta Lietuvos higienos norma HN 47-1:2012 - „Sveikatos priežiūros įstaigos. Infekcijų kontrolès reikalavimai“ “ [20]. Šiame teisès akte nustatytos visiems pacientams taikomos standartinès izoliavimo priemonès: rankų higiena, AAP dèvèjimas, per kraują ir (ar) kitus kūno skysčius plintančių infekcijų profilaktika, medicinos prietaisų ir gaminių apdorojimas, aplinkos paviršių valymas ir dezinfekcija [21], skalbinių ir atliekų tvarkymas [22] bei papildomos su perdavimo būdu (COVID-19 atveju - sąlyčio metu, per orą su lašeliais) susijusios izoliavimo priemonès [20, 1 ir 2 priedai]. Paminètina, kad pagrindiniai infekcijos kontrolès reikalavimai nebuvo keičiami paskelbus COVID-19 pandemiją, tačiau epidemiologinis režimas teikiant ASPP skirtingų kategorijų pacientams keitèsi, atsižvelgiant i tarptautinių organizacijų - PSO ir Europos ligų prevencijos ir kontrolès centro (toliau - ELPKC) rekomendacijas $[23,24]$, teikiamas atskirų kategorijų pacientams (COVID-19 ligoniai, ne COVID-19 pacientai, ịtariamieji COVID-19 pacientai), rekomendacijas dèl AAP lygių [25] bei jų dèvèjimo [26]. Pacientų kategorijos nustatymui lemiamą reikšmę turejjo COVID-19 apibréžtis [27], kuri keitėsi (Pastaba. Iki straipsnio pateikimo dienos COVID-19 apibrèžtis keitèsi 6 kartus) priklausomai nuo epidemiologinès situacijos (iš 
pradžių buvo siejama su grį̌zimu iš paveiktosios šalies, bet, prasidejjus vidiniam COVID-19 plitimui Lietuvos teritorijoje, buvo atsisakyta šio kriterijaus); turimų mokslo ịrodymų keitèsi įtarimui COVID-19 reikšmingi klinikiniai simptomai (Pastaba. İ COVID-19 ligai būdingų požymių sąrašą buvo itraukti kiti simptomai - uoslès ir skonio praradimas ar susilpnėjimas, nustatyti papildomi mažiau specifiški simptomai gali būti: galvos ir raumenų skausmas, šaltkrètis, nuovargis, vėmimas ir (ar) viduriavimas), atvejų klasifikavimas i įtariamą ir patvirtintą, buvo pakeistas ị galimą, tikètiną ir patvirtintą, atsižvelgiant ị klinikinių, laboratorinių ir epidemiologinių kriterijų derinị [28]. Todèl galima teigti, kad teisès aktuose iki pandemijos nustatyti bendrieji infekcijos kontrolès reikalavimai buvo pakankami, tačiau specialieji, susiję su COVID-19 valdymu, tiek teisès aktų reikalavimų, tiek soft law rekomendacijų šaltiniai buvo gausūs ir keitėsi labai dinamiškai ir tai koreliavo su besikeičiančia epidemiologine situacija.

Ambulatorinių asmens sveikatos priežiūros paslaugų teikimo teisinio reguliavimo pokyčiai ekstremalios epidemiologinès situacijos metu. COVID-19 priskyrimas prie ypač pavojingų užkrečiamųų ligų suteikẻ finansinio prieinamumo garantijas sergantiems COVID-19, tačiau vykdomajai valdžiai teko iššǔkis užtikrinti asmens sveikatos priežiūros paslaugų ekonominị, komunikacinị ir organizacinị prieinamumą [29, 2 str. 31 p.]. Ekspertai pabrēžia, kad prieinamumo sąlygų gerinimas sergantiems infekcinèmis ligomis yra kritiškai svarbus užtikrinant visuomenès sveikatos saugą [30]. Toliau straipsnyje nagrinèjami teisės aktai, kurių operatyvus prièmimas ir igyvendinimas leido greitą ambulatorinių asmens sveikatos priežiūros paslaugų (toliau - AASPP) formų plètrą ir paslaugų struktūros pasikeitimą. O tai tapo reikšmingu indèliu suvaldant pirmają COVID-19 plitimo bangą Lietuvoje.

\section{Naujos AASPP teikimo struktūros}

Karščiavimo klinikos. COVID-19 liga pasireiškia nespecifiniais viršutinių kvėpavimo takų infekcijos klinikiniais simptomais. Pacientai, turintys šiuos klinikinius požymius, laikomi ịtariamais sergant [27]. Savivaldybès buvo ịpareigotos organizuoti šio susirgimo diferencinę diagnostiką naujai steigiamuosiuose struktūriniuose-funkciniuose padaliniuose - karščiavimo klinikose [7].

Paslaugos karščiuojantiems pacientams gali būti teikiamos pirmines ASPP teikiančioje ASPI arba stacionarinès ASPI prièmimo-skubiosios pagalbos skyriuje, arba bet kurioje kitoje ASPĮ, kuri savivaldybės sprendimu paskirta karščiavimo klinika. Teisinis reglamentavimas aiškiai deleguoja paslaugų teikimo organizavimą savivaldybei, kaip institu- cijai, atsakingai už pirminės asmens sveikatos priežiūros ir už nustatyto masto antrinès asmens sveikatos priežiūros organizavimą [31], atsižvelgiant ị teikiamų besikreipiantiems pacientams paslaugų apimti [33]. Reguliavimo nuostatuose galime įžvelgti šiam laikotarpiui būdingą lankstumą: galimybę savivaldybėms pasitelkti sutartiniais pagrindais kitu savivaldybių isteigtas karščiavimo klinikas arba, gavus SAM rašytini pritarimą, jai pavaldžiose ASPI teikti karščiavimo klinikos paslaugas. Paslaugų teikimas karščiuojantiems pacientams organizuojamas teritoriniu principu, kuris gali nesutapti su įtvirtintais pirminiu ASPP teikimo organizavimo principais [32] ir paciento išreikšta valia dèl paslaugos teikèjo pasirinkimo.

Vertinant santykị su šeimos gydytojo institucija, pastebètina, kad karščiavimo klinikos atlieka kontaktinio paciento ištyrimo funkcijas; šeimos gydytojas, gavęs informaciją apie paciento ištyrimo rezultatus, apie juos informuoja karščiuojantị pacientą, prireikus skiria arba tęsia gydymą. Organizaciniu požiūriu karščiavimo klinikos teikia paslaugas visiems karščiuojantiems pacientams tiek dèl COVID-19, tiek dèl kitu priežasčių. Jų teikiamų paslaugų priskyrimas prie būtinosios pagalbos paslaugų [7, 6 p.], garantuoja jų apmokejjimą PSDF biudžeto lěšomis ir taip visiems karščiuojantiems pacientams suteikiama finansinio ịperkamumo garantija.

Paminėtina, kad be ịprastų infekcijų kontrolès reikalavimų laikymosi, kaip antai karččiuojančių ir nekarščiuojančių pacientų srautų atskyrimas ir valdymas, maksimaliai sumažinta pacientu tarpusavio kontakto galimybe ir kt. Numatyti ir specifiniai karččiavimo klinikos parinkimo kriterijai, siekiant užtikrinti epidemiologine prasme saugų komunikacinị prieinamumą, pvz., šiam tikslui parenkama įstaiga turi turèti patogu privažiavimą tiek lengvajam, tiek specialiajam transportui, kad, nesutrikdant automobilių eismo, galètų privažiuoti ir laukti eilèje ne mažiau kaip 10 automobilių [7].

Numatyta nemaža priemonių, leidžiančių užtikrinti darbuotojų saugą: nustatytas aukštas - ketvirtas iš galimų penkių - AAP dèvejimo lygis [25]; vadovu ịpareigojimas apmokyti darbuotojus tinkamai užsidèti ir nusiimti AAP [26]; numatomos organizacinès priemonès, minimalizuojančios tiesioginio kontakto su pacientu trukmę - išankstinè registracija, paciento pranešimas koordinatoriui apie atvykimą, bendravimo formą (raštu teikiami asmens duomenys atvykus) ir kt. Taip pat ir techninès ryšio priemonès (pacientas turi naudotis mobiliuoju telefonu, pranešdamas apie savo atvykimą). Pastebėtina, kad AAP dèvejjimo taisyklès derinamos su jų racionalaus naudojimo principu - vienkartinės apsaugos pirštinès keičiamos teikiant paslaugas kiekvienam pacientui, o kitos AAP nekeičiamos, jei nebuvo užterštos paciento sekretais.

Naujos AASPP teikimo struktūros - karščiavimo klini- 
kos įsteigimas leido užtikrinti ypač saugų epidemiologinių reikalavimų laikymąsi teikiant AASPP ir tradicinių kontaktinių paslaugų prieinamumą karščiuojantiems pacientams bei suteiké finansinio ịperkamumo garantiją.

Mobilieji punktai paimti tepinèlius laboratoriniams tyrimams dèl COVID-19 ligos. Kita unikali struktūrinèfunkcinè paslaugų teikimo naujovè - mobilusis punktas paimti tepinèlius iš asmens nosiaryklès ir ryklès laboratoriniams tyrimams dèl COVID-19. Kadangi teikiama AASPP priskirtina bendrosios praktikos slaugytojo kompetencijai [33], už šių paslaugų, kaip ir karščiavimo klinikų, organizavimą atsakingomis paskirtos kai kurių savivaldybių administracijos. Apskrities centro savivaldybès administracijos, pasitelkdamos jiems pavaldžias ASPĮ, privalo, o kitų savivaldybių administracijos - gali organizuoti mobiliujų punktų veiklą paskirtoje vietoje (aikšteje, automobilių stovejjimo aikštelèje, kurioje privažiuoti ir laukti eileje gali ne mažiau kaip 30 automobilių). Čia įrengiama palapine ir (ar) specialiosios paskirties transporto priemonè su patogiu privažiavimu ir išvažiavimu. Teisès aktas nustate darbuotojams aukščiausią (penktajį) AAP dèvèjimo lygi, minimalų mobiliojo punkto darbo laiką, registravimosi paslaugai gauti indikacijas ir būdą (pasitelkiant Karštają liniją), paslaugų teikimo tvarką minimizuojant tiesioginio kontakto su pacientu trukmę, panaudojant organizacines priemones, analogiškas taikomas karščiavimo klinikoms [34]. Šios naujos AASPP teikimo struktūros leido laiku užtikrinti diferencinę diagnostiką atliekant specifinius laboratorinius tyrimus. Beveik trečdalis ištirtų diagnostinių laboratorinių mėginių dèl COVID-19 ligos buvo paimti mobiliuosiuose punktuose (Pastaba. 2020 m. lapkričio 16 d. iš 1187 tūkst. COVID-19 mèginių mobiliuosiuose punktuose ištirta 340 tūkst., arba 28,6 procento). Be to, verta pažymèti, kad Lietuvos praktikoje unikalios struktūros mobiliujjų punktų steigimas - funkcinè alternatyva igyvendinti PSO ekspertu rekomendaciją dèl investicijų i ASPI pastatus, pritaikant juos prie infekcinių ligų paslaugų teikimo epidemiologinių reikalavimų $[2,30]$.

Karštoji linija 1808. Vienas iš didžiausių pandemijos valdymo iššūkių yra tinkama komunikacija individualaus paciento lygmeniu. Šiam uždaviniui ịgyvendinti Všl Kauno miesto greitosios medicinos pagalbos stotyje buvo ịsteigta Karštoji linija 1808 [35], kurios funkcijos - pacientų konsultavimas, registravimas ị karščiavimo klinikas, mobiliuosius punktus. Karštosios linijos 1808 darbuotojai ir savanoriai, nesantys sveikatos priežiūros specialistais, renka ir tvarko paciento asmens duomenis, o tai reiškia, kad šiems savanoriams nei specialiaisiais istatymais [29, 59 str.][36], nei poịstatyminiais teisès aktais [37] nesuteikta teisė be rašytinio paciento leidimo rinkti ir tvarkyti jo asmens duomenis.
Siekiant užtikrinti paciento duomenų apsaugą, teisès aktas [35] pateikè baigtinị sąrašą informacijos, kuri gali būti renkama, unifikavo informacijos rinkimo procesą pagal specialų struktūrizuotą skaitmeninį algoritmą, pritaikytą priimti ir apdoroti iškvietimus, nustatyti reikiamą pagalbos lygị ir rekomendacijas, nustate privalomą techninès apsaugos priemonę - pokalbių įrašymą, kuris šiuo atveju skirtas ne tik kontroliuoti renkamos informacijos apimti, paslaugos kokybę, bet ir naudojamas siekiant fiksuoti paciento ịsipareigojimą laikytis saviizoliacijos režimo nuo kreipimosi ị Karštają liniją dienos iki laboratorinio tyrimo rezultato gavimo. Vertinant reguliavimą pagal Bendrojo duomenų apsaugos reglamento taikomus reikalavimus, toks informacijos rinkimas yra galimas [38, 9 str. 2 d. i)], kadangi jị reglamentuoja nacionaliniai teisès aktai. Tačiau šios informacijos valdymas ir saugojimas nèra reglamentuotas teisès aktų, ir atsakomybè už tai tenka Všt Kauno miesto greitosios medicinos pagalbos stočiai [38, 9 str. 2 d. 3 p.]. Pastebètas ir pacientų, nesutinkančių, kad pokalbis būtų įrašytas, teisių suvaržymas, kadangi ị mobiliuosius punktus registraciją vykdo tik Karštoji linija 1808.

Nuotolinių AASPP teikimo reglamentavimo pokyčiai. Mokslininkai pastebi, kad COVID-19 pandemijos metu nuotolinių AASPP daugelyje šalių (pvz., Prancūzijoje, JAV) buvo diegiamos be aprobuotų standartų, sisteminio monitoringo ar įvertinimo, nesant aiškių etinių šių paslaugų teikimo metmenų, t.y. nesant sisteminio požiūrio dèl problemų, susijusių su nuotolinių paslaugų teikimu, sprendimo [5]. Štai Prancūzijoje pandemijos metu buvo leista pradèti teikti nuotolines ASPP pacientams su COVID-19 simptomatika ar patvirtinta liga, nereikalaujant, kad paslaugas teikiantis sveikatos priežiūros specialistas asmeniškai pažinotų pacientą. Tačiau pastebima, kad Italijos, kuri patyrè ypač sunkias COVID-19 pandemijos pasekmes, vykdomoji valdžia nesiryžo sureguliuoti nuotolinių ASPP ir integruoti ị valstybès kompensuojamų paslaugų nomenklatūrą [9]. Šiame kontekste yra svarbi Lietuvos patirtis, reglamentuojant tokias paslaugas.

2018 m. SAM įsakymas [39] numate naujos pirminès PAASPP formos - nuotolinès paslaugos (toliau - NP) atsiradimą. Ši paslauga teikiama šeimos gydytojo komandos nario, naudojantis informacinėmis ir elektroninių ryšių technologijomis, kuriomis yra galimybė identifikuoti asmeni. Nepaisant šios paslaugos teikimo formos inovatyvumo ir priimtinumo, daugeliui visuomenès nariu, reguliuojant NP teikimo indikacijas, buvo paisoma atsargumo principo ir nustatytos itin siauros jos teikimo indikacijos: teikiant NP galima pacientui skirti pakartotinius tyrimus, tęsti vaistinių preparatų ar medicinos pagalbos priemonių skyrimą [39, 24.1 p.], todèl šių paslaugų apimtys buvo mažos. Vis dèlto sukaupta patirtis reguliuojant NP ir jas teikiant, tapo labai ak- 


\section{4}

tuali, paskelbus karantiną dèl COVID-19. Teisinis reguliavimas plètėsi ir buvo implikuotas teikiant kitas paslaugas [40] - specializuotas AASPP, bendri NP teikimo principai nebuvo keisti (naudojamos informacinès technologijos, galimybė indentifikuoti pacientą, paslaugos registravimas medicinineje dokumentacijoje ir kt.). Šių NP plètrą ir svarbą lèmé šie reglamentavimo ypatumai: pirma, išplèstos paslaugų teikimo indikacijos - NP teikiamos ne tik ,gydytojas - pacientui“, bet ir ,gydytojas - gydytojui“; antra, teisès aktai nenumate NP teikimo apribojimų; trečia, siekiant minimizuoti tiesioginio kontakto būtinybę buvo nustatytas NP teikimo prioritetas, o tiesioginio kontakto paslaugos teikiamos tik tuomet, jei NP teikimui trūko duomenų apie paciento sveikatos būklę. Toks NP teikimo sąlygų sureguliavimas užtikrino, kad karantino laikotarpiu NP tapo pagrindine ambulatorinių paslaugų teikimo forma ir buvo sudarytos teisinès prielaidos nuotoliniu konsultacijų plètrai.

\section{Išvados}

1. Teisès aktuose iki pandemijos nustatyti bendrieji infekcijos kontrolès reikalavimai buvo pakankami, tačiau specialieji - susiję su COVID-19 valdymu, tiek teisès aktų reikalavimų, tiek soft law rekomendacijų šaltiniai buvo gausūs ir keitèsi labai dinamiškai ir tai koreliuoja su besikeičiančia epidemiologine situacija.

2. AASPP finansinis iperkamumas COVID-19 sergantiesiems ir karščiuojantiems pacientams buvo igyvendintas dviem teisinèmis priemonemis: pirma, COVID-19 infekcija buvo priskirta prie ypač pavojingų užkrečiamujų ligų; antra, AASPP karščiuojantiems pacientams buvo prilygintos būtinajai pagalbai.

3. Praejjus vos dešimčiai dienų po karantino paskelbimo, SAM priimti sprendimai iš esmès pakeite AASPP teikimo organizavimą, diegiant naujas jų teikimo pacientams organizacines struktūras - karščiavimo klinikas, mobiliuosius punktus, Karštają liniją 1808; teisinėmis priemonèmis įtvirtinta epidemiologiškai saugi ASPP teikimo forma - nuotolinių konsultacijų prioritetas. Šie sprendimai - sėkmingi tarptautinių rekomendacijų igyvendinimo lokaliu lygmeniu pavyzdžiai.

\section{Literatūra}

1. Lietuvos Respublikos Konstitucinio Teismo 2013 m. gegužès 16 d. nutarimas „Dèl pareigos mokèti valstybinio socialinio draudimo ir privalomojo sveikatos draudimo imokas, taip pat dèl motinystès (tèvystès) pašalpų sumažinimo“.

2. World Health Assembly, 58. Revision of the International Health Regulations. World Health Organization, (2005).

https://apps.who.int/iris/handle/10665/20353
3. Kandel N, Chungong S, Omaar A \& Xing J. Health security capacities in the context of COVID-19 outbreak: an analysis of International Health Regulations annual report data from 182 countries. The Lancet 2020.

https://doi.org/10.1016/S0140-6736(20)30553-5

4. Lietuvos Respublikos Vyriausybės $2020 \mathrm{~m}$. vasario 26 d. nutarimas Nr. 152 „Dèl valstybès lygio ekstremaliosios situacijos paskelbimo" (TAR, 2020-02-26, Nr. 2020-04023; 2020-06-11, Nr. 2020-12822; 2020-11-04, Nr. 2020-22950.

5. Salvador-Carulla L, Rosenberg S, Mendoza J, Tabatabaei-Jafari H, \& Network PMHI. Rapid response to crisis: Health system lessons from the active period of COVID-19. Health Policy and Technology. 2020.

https://doi.org/10.1016/j.hlpt.2020.08.011

6. Lietuvos Respublikos Vyriausybès $2020 \mathrm{~m}$. kovo $14 \mathrm{~d}$. nutarimas Nr. 207 „Dèl karantino Lietuvos Respublikos teritorijoje paskelbimo" (TAR, 2020-03-14, Nr. 2020-05466)

$7.2020 \mathrm{~m}$. kovo $23 \mathrm{~d}$. SAM ịsakymas Nr. V-506 „Dèl Ambulatoriniu asmens sveikatos priežiūros paslaugų viršutinių kvėpavimo takų infekcijos simptomų turintiems pacientams teikimo tvarkos aprašo patvirtinimo" (TAR, 2020-03-24, Nr. 2020-05926).

8. $2020 \mathrm{~m}$. kovo $16 \mathrm{~d}$. SAM įsakymas Nr. V-390 „Dèl Tepinèlių iš paciento nosiaryklès ir ryklès paèmimo mobiliuose punktuose COVID-19 ligos (koronaviruso infekcijos) laboratoriniams tyrimams atlikti organizavimo tvarkos aprašo patvirtinimo" (TAR, 2020-03-18, Nr. 2020-05658; 2020-04-02, Nr. 2020-06873).

9. Ohannessian R, Duong TA \& Odone A. Global telemedicine implementation and integration within health systems to fight the COVID-19 pandemic: a call to action. JMIR public health and surveillance 2020; 6(2): e18810.

https://doi.org/10.2196/18810

10. Keesara S, Jonas A \& Schulman K. Covid-19 and health care's digital revolution. New England Journal of Medicine 2020; 382(23): e82.

https://doi.org/10.1056/NEJMp2005835

11. Salvador-Carulla L, Rosenberg S, Mendoza J, Tabatabaei-Jafari H \& Network PMHI. Rapid response to crisis: Health system lessons from the active period of COVID-19. Health Policy and Technology 2020.

https://doi.org/10.1016/j.hlpt.2020.08.011

12. Pecchia L, Piaggio D, Maccaro A, Formisano C \& Iadanza E. The Inadequacy of Regulatory Frameworks in Time of Crisis and in Low-Resource Settings: Personal Protective Equipment and COVID-19. Health and Technology 2020; 1.

https://doi.org/10.1007/s12553-020-00429-2

13. Christensen T \& Lægreid P. Balancing governance capacity and legitimacy-how the Norwegian government handled the COVID-19 crisis as a high performer. Public Administration Review; Knieps F. 2020;.

https://doi.org/10.1111/puar.13241

14. Lietuvos Respublikos žmonių užkrečiamujų ligų profilaktikos ir kontrolès įstatymas (Žin., 1996, Nr. 104-2363; 2001, Nr. 
112-4069).

15. 2020 m. kovo 17 d. SAM įsakymas Nr. V-389 „Dèl SAM 2002 m. birželio 13 d. ịsakymo Nr. 278 „Dèl Pavojingu ir ypač pavojingų užkrečiamųjų ligų, dèl kurių ligoniai, asmenys, ịtariami, kad serga pavojingomis ar ypač pavojingomis užkrečiamosiomis ligomis, asmenys, turèję sąlytį, ar šių ligų sukèlèjų nešiotojai turi būti hospitalizuojami, izoliuojami, tiriami ir (ar) gydomi privalomai, sąrašo patvirtinimo" pakeitimo" (TAR, 2020-03-18, Nr. 2020-05670).

16. SAM ir Lietuvos Respublikos socialinès apsaugos ir darbo ministro $2020 \mathrm{~m}$. vasario $27 \mathrm{~d}$. įsakymu Nr. V-238/A1-170 „Dèl Elektroninių nedarbingumo pažymèjimų bei elektroninių néštumo ir gimdymo atostogų pažymėjimų išdavimo valstybės lygio ekstremaliosios situacijos ar karantino visos Lietuvos Respublikos mastu dèl COVID-19 ligos (koronaviruso infekcijos) plitimo grèsmès laikotarpiu laikinosios tvarkos aprašo patvirtinimo“"(TAR, 2020-02-28, Nr. 2020-04386; 2020-03-19, Nr. 2020-05779; 2020-06-16, Nr. 2020-13154).

17. Lietuvos Respublikos sveikatos draudimo ịstatymo 6 str. 4 d. 11 p. (Žin., 1996, Nr. 55-1287; 2002; Nr. 123-5512).

18. Lietuvos Respublikos Konstitucija (Lietuvos Aidas, 1992; 220(33): 1014.

19. LRV 2020 m. kovo 14 d. nutarimas Nr. 207 „Dèl karantino Lietuvos Respublikos teritorijoje paskelbimo“" (TAR, 202003-14, Nr. 2020-05466).

20. Lietuvos Respublikos sveikatos apsaugos ministro $2012 \mathrm{~m}$. spalio 19 d. ịsakymas Nr. V-946, Dèl Lietuvos higienos normos HN 47-1:2012, ,Sveikatos priežiūros ịstaigos. Infekcijų kontrolès reikalavimai“" patvirtinimo“ (Žin., 2012, Nr. 124-6241)

21. SAM 2011 m. balandžio 7 d. įsakymas Nr. V-327, Dèl Lietuvos higienos normos HN 90:2011 „Dezinfekcijos, dezinsekcijos ir deratizacijos bendrieji saugos reikalavimai“" patvirtinimo"

22. Medicininių atliekų reikalavimai taip pat nustatyti SAM 2013 m. liepos $18 \mathrm{~d}$. įsakymas Nr. V-706 „Dèl higienos normos HN 66:2013 „Medicininių atliekų tvarkymo saugos reikalavimai“ patvirtinimo"

23. https://www.who.int/emergencies/diseases/novel-coronavirus-2019/technical-guidance, žiūrèta 2020-11-07.

24. https://www.ecdc.europa.eu/en/all-topics-z/coronavirus/threats-and-outbreaks/covid-19/prevention-and-control-covid-19, žiūrèta 2020-11-07.

25. SAM $2020 \mathrm{~m}$. balandžio 7 d. sprendimas Nr. V-754 „Dèl asmeninès apsaugos priemonių naudojimo asmens sveikatos priežiūros įstaigose pagal saugumo lygius“" (TAR, 2020-04-08, Nr. 2020-07285).

26. https://SAM .lrv.lt/lt/koronavirusas/informacija-aspi-ir-sveikatos-prieziuros-specialistams-1/asmenines-apsaugos-priemonesir-ju-lygiai; https:/SAM .lrv.lt/uploads/SAM/documents/files/ KORONA/rekomendacijos\%20ASPI\%20del\%20AAP\%20 naudojimo.pdf, žiūrèta 2020-11-07.

27. 2020 m. kovo 10 d. SAM Nr. V-328 „Dèl COVID-19 ligos (koronaviruso infekcijos) atvejo apibrèžimo atnaujinimo“.

28. $2020 \mathrm{~m}$. birželio 15d. SAM - valstybès lygio ekstremaliosios situacijos valstybės operacijų vadovo sprendimas V-1461 „Dėl SAM - valstybès lygio ekstremaliosios situacijos valstybės operacijų vadovo $2020 \mathrm{~m}$. kovo $10 \mathrm{~d}$. sprendimo Nr. V-328, „Dèl COVID-19 ligos (koronaviruso infekcijos) atvejo apibrěžimo atnaujinimo" pakeitimo".

29. Lietuvos Respublikos sveikatos sistemos įstatymas (Žin., 1994, Nr. 63-1231; 1998, Nr. 112-3099).

30. Kandel N., Chungong S, Omaar A\&Xing J. Health security capacities in the context of COVID-19 outbreak: an analysis of International Health Regulations annual report data from 182 countries. The Lancet 2020.

https://doi.org/10.1016/S0140-6736(20)30553-5

31. Lietuvos Respublikos vietos savivaldos ịstatymo 6 str. 17 p. ir 7 str. 34 p. (Žin., 1994, Nr. 55-1049; 2000, Nr. 91-2832; 2008, Nr. 113-4290).

32. SAM 2001 m. lapkričio 9 d. įsakymas Nr. 583 „Dẻl Gyventojų prisirašymo prie pirminès asmens sveikatos priežiūros įstaigų tvarkos“ (Žin., 2001, Nr. 96-3400).

33. 2011 m. birželio 8 d. SAM ịsakymo Nr. V-591 „Dèl Lietuvos medicinos normos MN 28:2019 „Bendrosios praktikos slaugytojas“" patvirtinimo“"14.9.14 p. (Žin., 2011, Nr. 72-3490; TAR, 2019-07-15, Nr. 2019-11623).

34. $2020 \mathrm{~m}$. kovo $16 \mathrm{~d}$. SAM įsakymas Nr. V-390, „Dèl Tepinèlių iš paciento nosiaryklès ir ryklès paèmimo mobiliuose punktuose COVID-19 ligos (koronaviruso infekcijos) laboratoriniams tyrimams atlikti organizavimo tvarkos aprašo patvirtinimo" (TAR, 2020-03-18, Nr. 2020-05658; 2020-04-02, Nr. 2020-06873).

35. SAM $2020 \mathrm{~m}$. balandžio 27 d. sprendimas Nr. V-997 „Dèl darbo organizavimo Všl Kauno miesto greitosios medicinos pagalbos stotyje įsteigtoje sveikatos vartų „Koronos karštojoje linijoje 1808“ (TAR, 2020-04-28, Nr. 2020-08850).

36. Lietuvos Respublikos pacientų teisių ir žalos sveikatai atlyginimo įstatymo ịgyvendinimo įstatymo 8 ir 9 str. (Žin., 1996, Nr. 102-2318).

37. SAM 2001 m. vasario 1 d. įsakymas Nr. 65 „Dèl Informacijos apie pacientą valstybės institucijoms ir kitoms ịstaigoms teikimo tvarkos aprašo patvirtinimo ir Asmens sveikatos paslapties kriterijų nustatymo“" (Žin., 2001, Nr. 13-405; TAR, 2018-11-26, Nr. 2018-18986).

38. Europos Parlamento ir Tarybos Reglamentas (ES) 2016/679 $2016 \mathrm{~m}$. balandžio $27 \mathrm{~d}$. dèl fizinių asmenų apsaugos tvarkant asmens duomenis ir dèl laisvo tokių duomenų judejjimo ir kuriuo panaikinama Direktyva 95/46/EB (Bendrasis duomenų apsaugos reglamentas), Europos Sajungos oficialusis leidinys OL 119/1.

39. SAM 2005 m. gruodžio 5 d. įsakymas Nr. V-943 „Dèl Pirminès ambulatorinès asmens sveikatos priežiūros paslaugų teikimo organizavimo ir šių paslaugų išlaidų apmokèjimo tvarkos aprašo tvirtinimo“ (Žin., 2005, Nr. 143-5205; TAR, 2018-0206, Nr. 2018-01808).

40. SAM 2020 m. kovo 16 d. sprendimas Nr. V-387 „Dèl asmens sveikatos priežiūros paslaugų teikimo organizavimo paskelbus karantiną Lietuvos Respublikos teritorijoje“"(TAR, 2020-03-17, 
Nr. 2020-05561; 2020-03-27, Nr. 2020-06151), pakeistas SAM 2020 m. birželio 17 d. ịsakymas Nr. V-1504 „Dèl Asmens sveikatos priežiūros paslaugų teikimo esant Lietuvos Respublikos teritorijoje paskelbtai valstybès lygio ekstremaliajai situacijai organizavimo tvarkos aprašo patvirtinimo“" (TAR, 2020-06-17, Nr. 2020-13262).

\section{REGULATION ENSURING THE AVAILABILITY AND SAFETY OF OUTPATIENT HEALTH CARE SERVICES IN THE FACE OF COVID-19 SPREAD \\ J. Kutkauskienė}

Keywords: COVID-19 outbreak, health care institutions, services for COVID-19 patients.

Summary

Decisions in health care are usually based on medical evidence. However, during the COVID-19 pandemic, the executive power had the responsibility to make urgent decisions in the absence of scientific evidence and to implement international recommendations tailored to specific local conditions. The pursuit of ensuring the availability and safety of health care services required timely legal regulation, which can be conditionally divided into these main categories: regulation establishing a special epidemiological regime in health care institutions and changes in the regulation of providing health care services. This research revealed that the general infection control requirements set out in the pre-pan- demic legislation were sufficient, but the specific regulation, related to the management of COVID-19 spread (both, legal requirements and the soft law recommendations) were numerous and changed very dynamically due to the changing epidemiological situation. Legislative measures ensured the financial affordability of health care services for COVID-19 and febrile patients. Just ten days after the announcement of the quarantine, the decisions taken by the Ministry of Health fundamentally changed the organization of outpatient health care services by introducing new organizational structures for patients - fever clinics, mobile points, Hotline 1808, and legally regulated the provision of epidemiologically safe tele-medicine (i.e. remote) health care services. These solutions are successful examples of the implementation of international recommendations at the local level.

Correspondence to: jelena.kutkauskiene@gmail.com

Gauta 2020-11-19 